Sains Peternakan Vol. 13 (1), Maret 2015: 36-45

ISSN 1693-8828

\title{
Pengaruh Penambahan Gula Kelapa Pasta pada Ensilase Ikan Rucah Terhadap Kualitas Silase
}

\author{
Efka Aris Rimbawanto ${ }^{1 *}$, Lies Mira Yusiati ${ }^{2}$, Endang Baliarti $^{2}$ dan Ristianto Utomo ${ }^{2}$ \\ ${ }^{1}$ Fakultas Peternakan, Universitas Jenderal Soedirman, Jl. Dr. Soeparno No. 60, Purwokerto 53122 \\ ${ }^{2}$ Fakultas Peternakan, Universitas Gadjah Mada, Jl. Fauna 3, Yogyakarta 55281 \\ Contact person: Ir. Efka Aris Rimbawanto,MP. \\ Fakultas Peternakan, Universitas Jenderal Soedirman, Jl. Dr. Soeparno No. 60, Purwokerto 53122, \\ Telp.624504, email:fk.aris.r@gmail.com
}

\begin{abstract}
ABSTRAK
Penelitian ini bertujuan untuk mengkaji pengaruh aras gula kelapa pasta dalam ensilase ikan rucah secara fermentasi alami terhadap perubahan kimiawi. Ikan rucah (Pomadasys macullatus) giling dicampur dengan dengan gula kelapa pasta $(0,15,30$ dan 45\%/kg ikan rucah segar) tanpa inokulasi dalam kantong plastik. Inkubasi dilakukan secara anaerob pada suhu ruang $\left(29^{\circ} \pm 1^{\circ} \mathrm{C}\right)$. Perubahan kimiawi ( $\mathrm{pH}$, asam laktat, amonia, non protein nitrogen, bilangan peroksida dan asam lemak bebas) diamati pada periode fermentasi 0 , 4, 8, 12, 16, 20 dan 24 hari. Percobaan dilakukan dengan menggunakan rancangan acak kelompok untuk memilih jumlah gula kelapa pasta dan waktu fermentasi terbaik dalam ensilase ikan rucah. Ikan rucah segar dan produk fermentasi (silase ikan rucah) dianalisis proksimat (bahan kering, abu, protein kasar dan lemak kasar). Hasil mengidikasikan terjadi penurunan $\mathrm{pH}$ tetap konstan 4,4 setelah 16 hari fermentasi. Asam laktat, amonia, non protein nitrogen, bilangan peroksida dan asam lemak bebas selama fermentasi meningkat secara nyata karena perbedaan aras gula kelapa pasta dan waktu fermentasi. Disimpulkan gula kelapa pasta $15 \% / \mathrm{kg}$ ikan rucah segar, merupakan campuran terbaik dalam fermentasi alami dengan waktu fermentasi 16 hari dan produk berpotensi sebagai bahan sumber protein $(45 \% \mathrm{BK})$ dalam pakan ternak.
\end{abstract}

Kata kunci: ikan rucah, gula kelapa pasta, silase, fermentasi.

\section{The Influence of Additional of Coconut Sugar Paste in Trash Fish Ensilage to Silage Quality}

\begin{abstract}
The objective of this research was to analyze the effect of coconut sugar paste in naturally fermented trash fish ensilage on chemical change. Grinded trash fish (Pomadasys macullatus) was mixed with coconut sugar paste $(0,15,30$ and $45 \% / \mathrm{kg}$ fresh trash fish) without inoculation in plastic bag. Anaerobe incubation was conducted at room temperature $\left(29^{\circ} \pm 1^{\circ} \mathrm{C}\right)$. Chemical change ( $\mathrm{pH}$, lactic acid, ammonia, non-protein nitrogen, peroxide value and free fatty acid) was observed during fermentation period of $0,4,8,12,20$ and 24 days. The experiment which had a completely randomized design to select the best amount of coconut sugar paste and fermentation period in trash fish ensilage. Fresh trash fish and fermentation product (trash fish silage) determined by the proximate analysis (dry matter, ash, crude protein and crude fat). Result indicated that the pH decreased remained constan at 4,4 after 16-day fermentation. Lactic acid, ammonia, non-protein nitrogen, peroxide value and free fatty acid during fermentation significantly increased due to different levels of coconut sugar paste and fe rmentation period. Conclusively, coconut sugar paste at the
\end{abstract}


level of $15 \% / \mathrm{kg}$ fresh trash fish was the best combination in natural fermentation with 16-day fermentation period and the product was potential protein source (45\% DM) for animal feed.

Key word: Trash fish, coconut sugar paste, silage, fermentation.

\section{PENDAHULUAN}

Ikan rucah (trash fish) adalah istilah yang digunakan untuk berbagai spesies ikan laut yang umumnya berukuran kecil, tidak disukai konsumen dan tidak mempunyai nilai komersial langsung (FAO, 2005). Produksi ikan laut di Indonesia (FAO, 2004), sebanyak 3.104.788 ton/tahun dan 270.412 ton berupa ikan rucah. Pemanfaatan ikan rucah umumnya masih terbatas dalam bentuk ikan asin, pakan ikan dan unggas. Jumlah yang besar ini sangat potensial sebagai bahan baku pakan ternak, tetapi ikan segar mudah rusak.

Kerusakan terjadi karena enzim yang mencerna makanan di usus berlanjut ke daging ikan hingga ketersediaan energi habis diikuti dengan kerusakan aerobik (Gram, 2009). Kontaminasi dengan mikrobia pembusuk tidak bisa dihindari karena ikan merupakan media yang baik untuk pertumbuhan. Mikrobia akan memetabolisme asam amino menghasilkan amonia, amina biogenik (putresin, histamin dan kadaverin), asam organik dan senyawa sulfur, sehingga beraroma tidak sedap.

Upaya penanganan dan pengawetan yang cukup efesien dan murah dengan dibuat silase secara fermentasi menggunakan asam laktat yang diproduksi oleh bakteri asam laktat (Abowei dan Tawari, 2011). Ikan kandungan karbohidratnya rendah, sehingga dalam pembuatan silase ikan perlu ditambah sumber karbohidrat untuk menumbuhkan bakteri asam laktat. Sumber karbohidrat yang sesuai untuk produksi asam laktat yang cukup untuk pengawetan dapat mengurangi kerusakan terutama di awal fermentasi.

Sumber karbohidrat yang telah digunakan dalam ensilase ikan berupa tetes tebu (Zahar et al., 2002; Schneider et al.,
2006), karena dapat mengoptimalkan pertumbuhan bakteri asam laktat. Akan tetapi, pada daerah penghasil ikan rucah terkendala dalam ketersediaan tetes tebu, sehingga perlu diganti dengan sumber karbohidrat yang tersedia. Ketersediaan gula kelapa pasta di wilayah pesisir dapat dijadikan solusi untuk menggantikan tetes tebu. Gula kelapa pasta termasuk sumber karbohidrat yang mudah larut dan belum dimanfaatkan. Gula kelapa pasta adalah produk yang tidak jadi dalam pembuatan gula kelapa, karena tidak dapat mengental dan tidak dapat dicetak, sehingga tidak mempunyai nilai ekonomis. Penggunaan gula kelapa pasta memungkinkan untuk menggantikan penggunaan tetes tebu pada ensilase ikan, karena kandungan sukrosa, glukosa dan fruktosa pada tetes tebu 35, 7 dan 9\% (Teclu et al., 2009), sedangkan pada gula kelapa 35, 5, dan 4\% (Apriyantoet al., 2002).

Penelitian ini bertujuan untuk mengkaji pengaruh aras gula kelapa pasta dalam ensilase ikan rucah secara fermentasi alami terhadap perubahan kimiawi (perubahan keasaman, fraksi nitrogen, oksidasi lipid dan komposisi kimia).

\section{MATERI DAN METODE}

\section{Bahan Baku}

Ikan non ekonomis (rucah) yaitu ikan coklatan (Pomadasys macullatus) segar berasal dari Tempat Pelelangan Ikan Cilacap. Gula kelapa pasta berasal dari pengrajin gula kelapa di Kecamatan Cilongok, Kabupaten Banyumas.

\section{Preparasi Silage}

Ikan rucah segar $(27,19 \%$ BK) yang telah digiling dengan Disk Mill (Model FFC15) ditambah gula kelapa pasta $(75 \%$ BK). 
Jumlah gula kelapa yang ditambahkan 0, 15, 30 dan 45\%/kg ikan rucah. Campuran ikan rucah giling dan gula kelapa pasta ditempatkan dalam kantong plastik (diameter $15 \mathrm{~cm}$ dan tinggi $60 \mathrm{~cm}$ ). Campuran tersebut menempati sepertiga bagian dari kantong platik dan dua per tiga dalam keadaan vakum untuk ruang dari gas yang dihasilkan selama fermentasi. Fermentasi dilakukan secara alami dan inkubasi dilakukan secara anaerob pada suhu ruang $\left(29^{\circ} \pm 1^{\circ} \mathrm{C}\right)$ selama $0,4,8,12,16$, 20 dan 24 hari.

Efektivitas ensilase ikan rucah diuji berdasarkan penurunan keasaman media dan kualitas silase. Pengukuran keasaman silase ikan rucah diukur dengan menggunakan $\mathrm{pH}$ meter (AOAC, 2002) dan produk asam laktat diukur dengan spektrofotometer menggunakan p-hidroksidifenil (Baker dan Summerson, 1941). Degradasi protein selama ensilase ikan rucah diukur bardasarkan kandungan nitrogen total, non-protein nitrogen dengan metode Kjeldahl (AOAC, 2002). Amonia diukur menggunakan spektrofotometer dengan reaksi warna fenolhypochlorit (Weatherburn, 1967) dari filtrat hasil pengendapan protein silase ikan rucah menurut cara Pearson (1971). Degradasi asam lemak selama ensilase ikan rucah diukur bilangan peroksida dan asam lemak bebas (Nielsen, 2010). Perubahan kualitas ikan rucah sebelum dan setelah fermentasi di analisis proksimat (air, abu, protein kasar dan lemak kasar) menurut cara AOAC (2002).

\section{Analisa Data}

Percobaan ensilase ikan rucah dilakukan dengan Rancangan Acak Kelompok dengan perlakuan 4 macam aras gula kelapa pasta yang ditambahkan $(0,15,30$ dan $45 \%)$ dalam ikan rucah giling dan 7 kelompok lama fermentasi $(0,4,8,12,16,20$ dan 24 hari), setiap kelompok dalam perlakuan diulang 3 kali. Data yang diperoleh dianalisis variansi, bila ada perbedaan antara rataan perlakuan di uji dengan Duncan's new multiple range test. Pengolahan data dilakukan dengan program IBM SPSS Statistics (2013). Pemilihan aras gula kelapa pasta untuk ensilase ikan rucah berdasarkan perubahan kualitas kimiawi dan komposisi proksimat.

\section{HASIL DAN PEMBAHASAN}

\section{Perubahan pH dan Produk Asam Laktat Silase Ikan Rucah}

Nilai $\mathrm{pH}$ dan produk asam laktat silase ikan rucah selama fermentasi pada suhu $29^{\circ} \pm 1^{\circ} \mathrm{C} \quad$ dipengaruhi $\quad(\mathrm{P}<0,01) \quad$ oleh penambahan gula kelapa pasta dan waktu fermentasi. Perubahan nilai $\mathrm{pH}$ (Gambar 1), menunjukkan penurunan dari 7,0 menjadi 4,4 konstan setelah 16 hari fermentasi. Menurunnya $\mathrm{pH}$ karena meningkatnya produksi asam laktat (Gambar 2) dan kostan setelah 16 hari fermentasi dengan produksi asam laktat 33,5 g/100 g silase $(0,91 \% \mathrm{BK})$. Penurunan $\mathrm{pH}$ dan peningkatan produk asam laktat sebagai bukti terjadi proses fermentasi oleh bakteri asam laktat. Aras gula kelapa pasta $15 \%$ menunjukkan hasil yang sama dengan aras gula kelapa pasta 30 dan $45 \% / \mathrm{kg}$ ikan rucah segar, karena meningkatnya aras gula kelapa pasta tidak mempengaruhi $(\mathrm{P}>0,05)$ penurunan $\mathrm{pH}$ maupun peningkatan produk asam laktat selama fermentasi. 


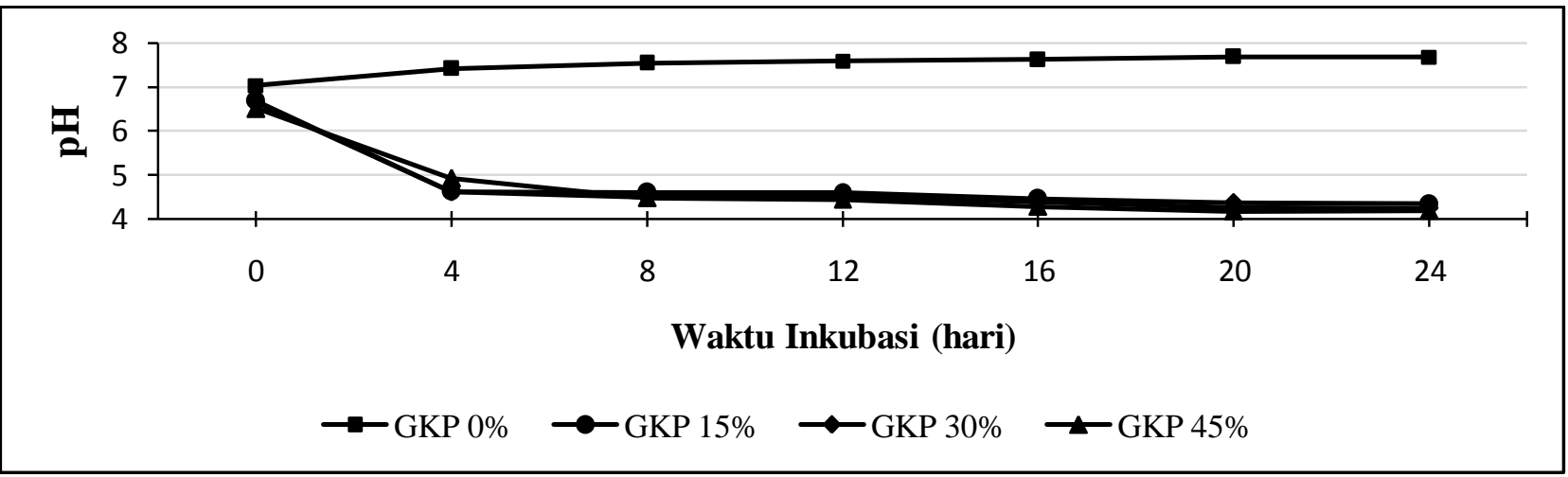

Gambar 1. Perubahan $\mathrm{pH}$ selama fermentasi alami ikan rucah yang ditambah gula kelapa pasta (GKP) 0,15 , 30 , dan $45 \% / \mathrm{kg}$ ikan rucah segar pada inkubasi suhu ruang $\left(29^{\circ} \pm 1^{\circ} \mathrm{C}\right)$ secara anaerob.

Peningkatan $\mathrm{pH}$ dan tidak adanya produk asam laktat terjadi pada fermentasi tanpa penambahan gula kelapa pasta, karena terjadi kerusakan otolisis dari enzim proteolitik dan mikroorganisme yang merugikan sehingga menghasilkan amonia, biogenik amin dan sulfur (Gram, 2009). Produk degradasi protein menunjukkan $\mathrm{pH}$ netral sampai basa (Ghaly et al., 2010), sehingga menyebabkan peningkatan nilai $\mathrm{pH}$ pada silase ikan rucah yang tidak ditambah gula kelapa pasta.
Penambahan gula kelapa pasta $15 \% / \mathrm{kg}$ ikan rucah segar selama fermentasi mampu meningkatkan produk asam laktat sehingga menurunkan keasaman hingga $\mathrm{pH}$ pengawetan $(\leq 4,5)$. Tercapainya $\mathrm{pH}$ pengawetan, terjadi penghambatan pertumbuhan mikroorganisme yang merugikan produk dan fermentasi dapat dihentikan (Dapkevicius et al., 2007). Selama fermentasi bakteri asam laktat selain menghasilkan asam laktat, juga menghasilkan beberapa metabolit (bacteriocin) yang membantu pengawetan produk fermentasi makanan (Axelsson, 2004).

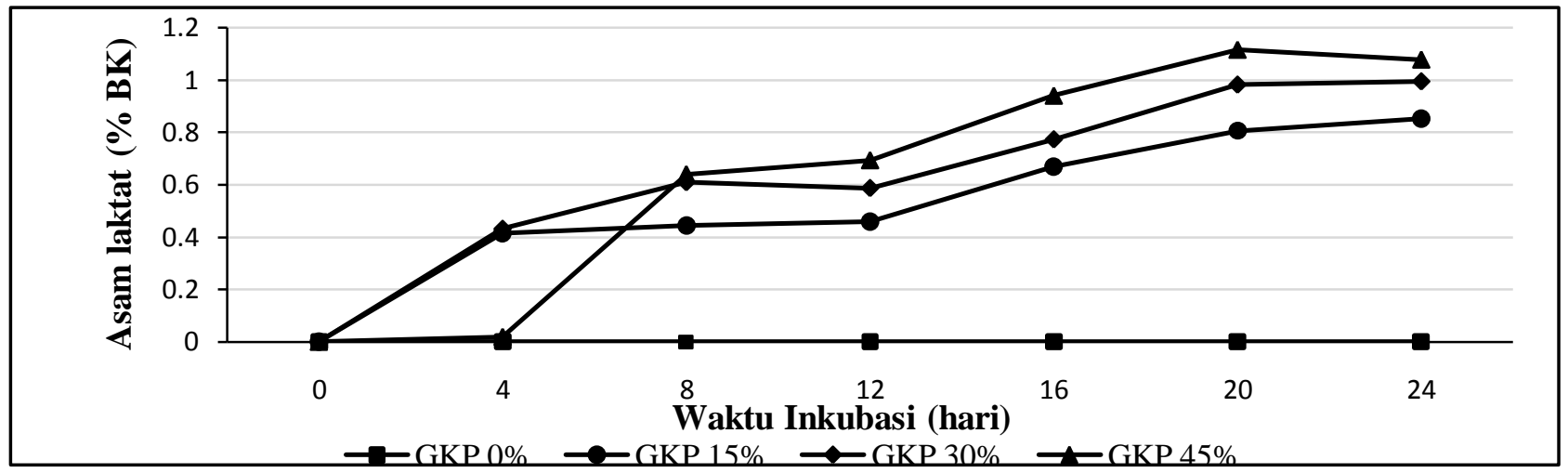

Gambar 2. Perubahan produk asam laktat selama fermentasi alami ikan rucah yang ditambah gula kelapa pasta (GKP) $0,15,30$ dan $45 \% / \mathrm{kg}$ ikan rucah segar pada inkubasi suhu ruang $\left(29^{\circ} \pm 1^{\circ} \mathrm{C}\right)$ secara anaerob 


\section{Fraksi Nitrogen Silase Ikan Rucah}

Perbedaan aras gula kelapa pasta dan waktu fermentasi berpengaruh $(\mathrm{P}<0,01)$ terhadap kandungan amonia (Gambar 3) dan non protein nitrogen silase ikan rucah (Gambar 4). Selama fermentasi kandungan amonia silase ikan rucah meningkat $(\mathrm{P}<0,05)$ dan kandungan amonia stabil setelah 16 hari fermentasi. Meningkatnya aras gula kelapa pasta $(0,15,30$ dan $45 \% / \mathrm{kg}$ ikan rucah segar) menurunkan $(\mathrm{P}<0,05)$ kandungan amonia berturut-turut 1,$33 ; 1,32 ; 1,13 ; 0,87 \% \mathrm{~N}$ total pada kondisi stabil. Stabilnya kandungan amonia setelah 16 hari fermentasi karena tercapainya $\mathrm{pH}$ pengawetan $(\leq 4,5)$, sehingga mampu menghambat pertumbuhan mikroorganisme yang mendegradasi protein.

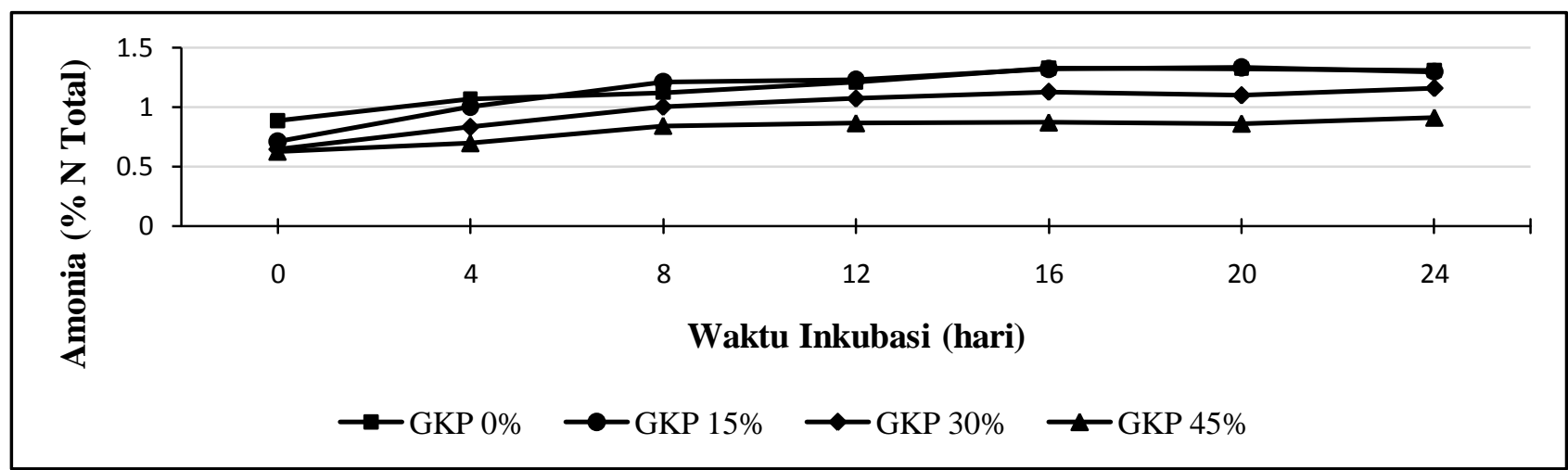

Gambar 3. Perubahan amonia selama fermentasi alami ikan rucah yang ditambah gula kelapa pasta (GKP) 0 , 15,30 dan $45 \% / \mathrm{kg}$ ikan rucah segar pada inkubasi suhu ruang $\left(29^{\circ} \pm 1^{\circ} \mathrm{C}\right)$ secara anaerob.

Fermentasi ikan umumnya kandungan amonia meningkat, karena terbentuknya nitrogen volatil (amonia dan trimetilamin) dari aktivitas enzim yang berasal dari jaringan atau viscera ikan dan deaminasi asam amino (Daalgaard et al., 2006; Ndaw et al., 2008). Hasil penelitian juga menunjukkan bahwa fermentasi ikan rucah tanpa penambahan gula kelapa pasta (kontrol) terjadi degradasi protein yang berlanjut ke proses pembusukan. Berbeda dengan fermentasi ikan rucah yang ditambah gula kelapa pasta $(15 \% / \mathrm{kg}$ ikan rucah) dapat menurunkan degradasi protein. Hal ini disebabkan karena subtrat untuk pertumbuhan bakteri asam laktat adalah karbohidrat terutama glukosa (Axelsson, 2004) dan adanya produk metabolit dari bakteri asam laktat mampu menghambat mikroorganisme yang mendegradasi protein (Dapkevicius et al., 2007).

Kandungan non protein nitrogen ikan rucah segar $12,63 \% \mathrm{~N}$ total, selama fermentasi kandungan non protein nitrogen mengalami peningkatan $(\mathrm{P}<0,05)$ dan stabil setelah 16 hari fermentasi. Kondisi stabil kandungan non protein nitrogen silase ikan rucah antara aras gula kelapa pasta berbeda $(\mathrm{P}<0,05)$, pada aras $0,15,30$ dan $45 \% / \mathrm{kg}$ ikan rucah berturut-turut kandungan non protein nitrogen 65,74; 42,05; 36,$14 ; 33,62 \% \mathrm{~N}$ total. Proses pembusukan terjadi pada fermentasi silase ikan rucah yang tidak ditambah gula kelapa pasta (kontrol) sehingga protein terdegradasi pada awal fermentasi oleh aktivitas enzim jaringan dan selanjutnya diikuti dengan tumbuhnya bakteri pembusuk (Gram, 2009). 


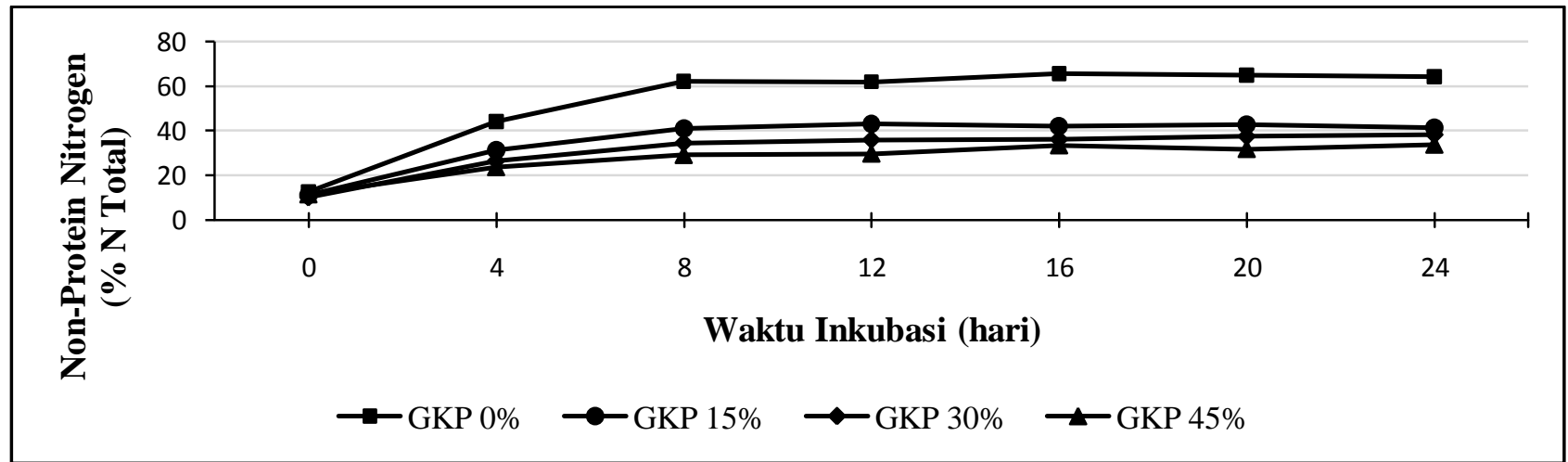

Gambar 4. Perubahan non protein nitrogen selama fermentasi alami ikan rucah yang ditambah gula kelapa pasta (GKP) $0,15,30$ dan $45 \% / \mathrm{kg}$ ikan rucah segar pada inkubasi suhu ruang $\left(29^{\circ} \pm 1^{\circ} \mathrm{C}\right)$ secara anaerob.

Kandungan non protein nitrogen dalam penelitian ini masih dibawah dari hasil penelitian sebelumnya pada silase ikan tilapia yang menggunakan tetes tebu 15\%/ikan tilapia dengan kandungan non protein nitrogen $46 \% \mathrm{~N}$ total (Fagbenro dan Jauncey, 1993) dan pada silase viscera ikan yang ditambah tetes tebu $10 \%$ dengan kandungan non protein nitrogen $61,02 \% \mathrm{~N}$ total (Ahmed dan Mahendrakar, 1996). Perbedaan kandungan non protein nitrogen selama fermentasi silase ikan atau limbah ikan dipengaruhi oleh perbedaan kecepatan penurunan $\mathrm{pH}$, sehingga aktivitas enzim dari jaringan berbeda pula (Dapkevicius et al., 2007).

\section{Oksidasi Lipid Silase Ikan Rucah}

Selama ensilase ikan rucah, lemak dapat mengalami perubahan baik secara oksidatif, degradasi oleh enzim jaringan dan mikroorganisme yang menyebabkan perubahan kualitas lemak silase. Perubahan bilangan peroksida (Gambar 5) dan asam lemak bebas (Gambar 6) selama fermentasi ikan rucah dipengaruhi $(\mathrm{P}<0,01)$ oleh aras penambahan gula kelapa pasta dan waktu fermentasi. Selama fermentasi terjadi peningkatan $(\mathrm{P}<0,05)$ bilangan peroksida hinga hari ke-4 fermentasi kemudian menurun dan stabil setelah 16 hari fermentasi. Bilangan peroksida pada kondisi stabil antara aras penambahan gula kelapa pasta $(0,15,30$ dan $45 \% / \mathrm{kg}$ ikan rucah) berbeda $(\mathrm{P}<0,05)$ berturut-turut 12,$17 ; 6,16 ; 5,22 ; 4,14 \mathrm{mEq} / \mathrm{kg}$ lemak. 


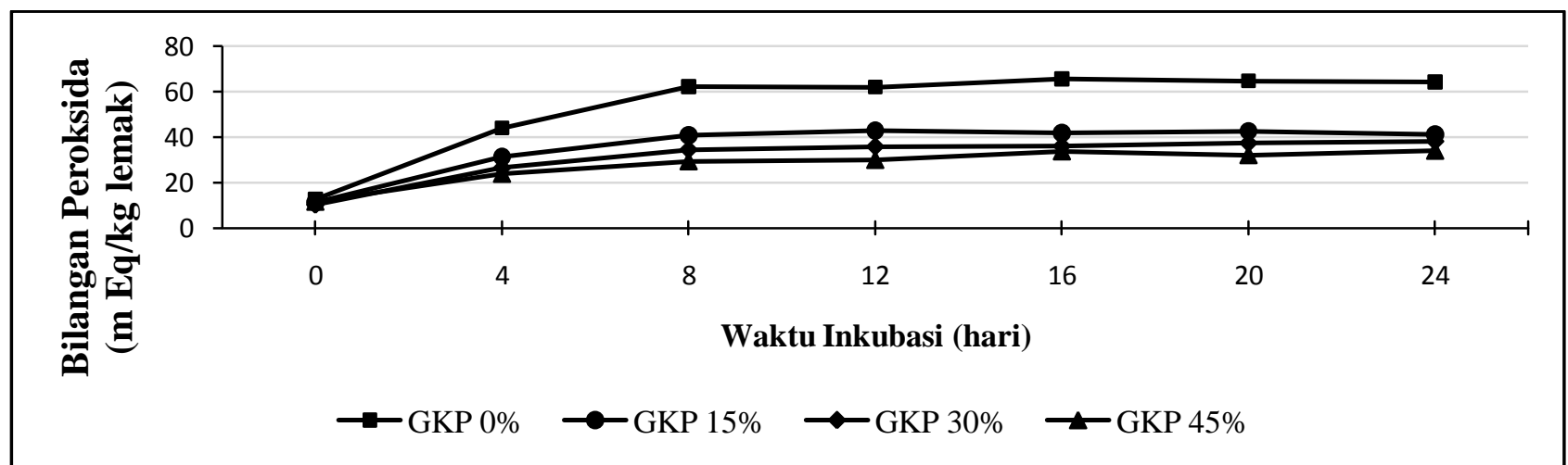

Gambar 5. Perubahan bilangan peroksidaselama fermentasi alami ikan rucah yang ditambah gula kelapa pasta (GKP) $0,15,30$, dan $45 \% / \mathrm{kg}$ ikan rucah segar pada inkubasi suhu ruang $\left(29^{\circ} \pm 1^{\circ} \mathrm{C}\right)$ secara anaerob.

Lemak ikan terdiri dari asam lemak tak jenuh dan sejumlah besar ikatan rangkapnya sangat rentan terhadap oksidasi (otoksidasi) membentuk hidroperoksida (Repetto et al., 2012). Hidroperoksida juga dihasilkan dari otoksidasi komponen hematin (hemoglobin, myoglobin dan cytokrom) (Ghaly et al., 2010). Bilangan peroksida ikan rucah sebelum fermentasi menunjukkan terjadinya pelepasan asam lemak tak jenuh dari sel-sel selama proses penggilingan, sehingga mudah teroksidasi, bilangan peroksida ikan rucah giling sebelum fermentasi 7,57 $\mathrm{mEq} / \mathrm{kg}$ lemak. Bilangan peroksida dalam penelitian ini lebih rendah dibanding bilangan peroksida ikan blue whiting pada awal fermentasi $18 \mathrm{mEq} / \mathrm{kg}$ lemak (Dapkevicius et al., 2007) dan pada ikan tilapia $143 \mathrm{mEq} / \mathrm{kg}$ lemak (Fagbenro dan Jauncey, 1993). Perbedaan tersebut karena kandungan asam lemak jenuh setiap spesies ikan tidak sama.

Peningkatan bilangan peroksida pada awal fermentasi karena terjadi otoksidasi, kemudian menurun dan stabil setelah 16 hari fermentasi, karena rusaknya hidroperoksida dan terbentuknya peptida selama proses fermentasi ikan rucah. Peptida yang terbentuk selama fermentasi vicera ikan memiliki aktivitas antioksidan yang dapat mencegah oksidasi lipid (Sachindra dan Bhaskar, 2008; Raia et al., 2010). Fermentasi hingga hari ke24 pada silase ikan rucah yang ditambah gula kelapa pasta menunjukkan tidak beraroma tengik (5,191-6,612 $\mathrm{mEq} / \mathrm{kg}$ lemak) yang awalnya sebelum fermentasi.

Ikan rucah giling sebelum fermentasi kandungan asam lemak bebas (\% asam oleat) $2,12 \pm 0,12 \%$. Perbedaan kandungan asam lemak bebas $(\mathrm{P}<0,05)$ antara kontrol dengan silase ikan rucah yang ditambah gula kelapa pasta, sedangkan antara aras gula kelapa pasta dan waktu fermentasi tidak berbeda $(\mathrm{P}>0,05)$. Hal ini disebabkan karena adanya penghambatan aktivitas lipase oleh asam laktat yang diproduksi bakteri asam laktat yang tumbuh selama fermentasi ikan rucah yang ditambah gula kelapa pasta. Menurut Raia et al. (2010), menurunnya asam lemak bebas selama fermentasi menurunkan aktivitas lipase dengan menurunnya $\mathrm{pH}$. 


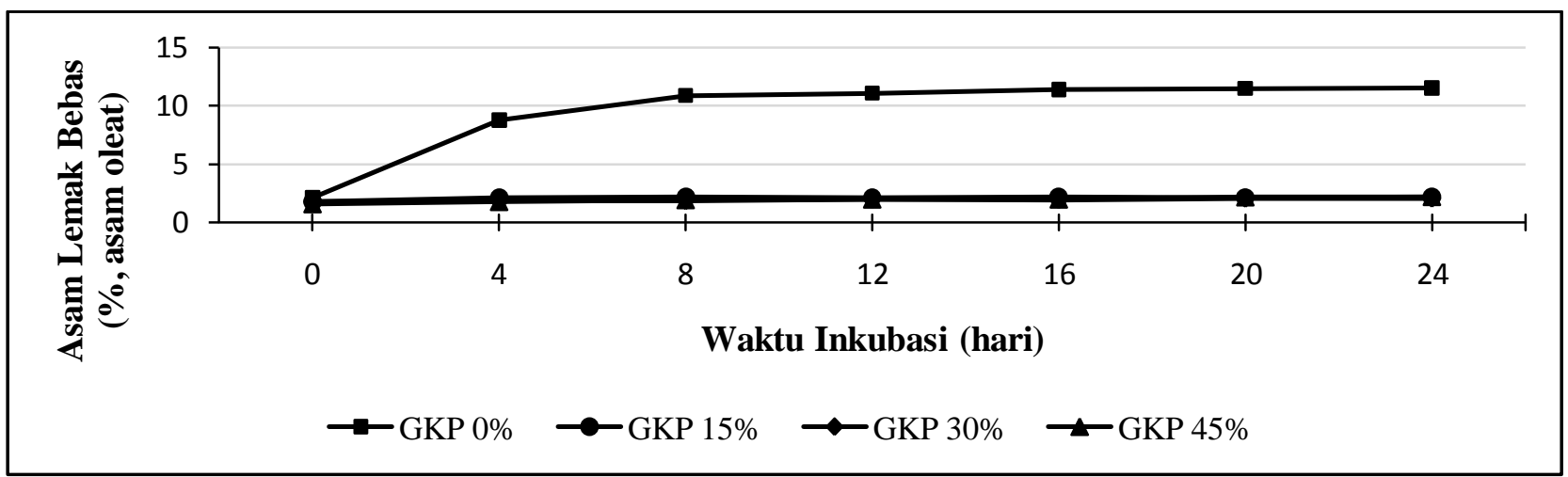

Gambar 6. Perubahan asam lemak bebas selama fermentasi alami ikan rucah yang ditambah gula kelapa pasta $(\mathrm{GKP}) 0,15,30$ dan $45 \% / \mathrm{kg}$ ikan rucah segar pada inkubasi suhu ruang $\left(29^{\circ} \pm 1^{\circ} \mathrm{C}\right)$ secara anaerob.

Peningkatan asam lemak bebas pada awal fermentasi, karena vicera ikan mengandung enzim tinggi dan mempunyai aktivitas tinggi, walaupun dalam suhu penyimpanan rendah (Rustad et al., 2011). Menurut Raia et al. (2010) melaporkan bahwa selama fermentasi ikan atau limbah ikan, hidrolisis protein jaringan diikuti dengan pelepasan minyak yang dihidrolisis oleh lipase dan fosfolipase menjadi asam lemak bebas. Kerusakan lipid pada ikan selama penyimpanan tidak hanya aktivitas lipase dari enzim jaringan tetapi dapat berasal dari mikrobia perusak (Ghaly et al., 2010; Gram, 2009).

\section{Komposisi Proksimat Silase Ikan Rucah}

Kandungan nutrien silase ikan rucah lebih rendah dibanding ikan rucah segar, karena pada awal fermentasi tidak dapat dihindari terjadi degradasi oleh mikroorganisme. Perubahan kimiawi $(\mathrm{pH}$, asam laktat, fraksi nitrogen dan oksidasi lipid) silase ikan rucah yang ditambah gula kelapa setelah 16 hari fermentasi baru mencapai stabil (tidak mengalami perubahan), sehingga proses fermentasi dapat dihentikan. Hasil analisis proksimat ikan rucah dan silase ikan rucah setelah 16 hari fermentasi (produk) tertera pada Tabel 1 .

Tabel 1. Kandungan Bahan Kering, Abu, Protein Kasar dan Lemak Kasar Ikan Rucah dan Silase Ikan Rucah Pada Aras Gula Kelapa Pasta (15, 30 dan 45\%/kg Ikan Rucah Segar)

\begin{tabular}{llccc}
\hline & & \multicolumn{3}{c}{ Silase ikan rucah (fermentasi 16 hari) } \\
\cline { 2 - 4 } & Ikan rucah & \multicolumn{2}{c}{ Aras gula kelapa pasta (\%/kg ikan rucah segar) } \\
\cline { 2 - 4 } & segar & 15 & 30 & 45 \\
\hline Bahan kering, \% & $27,19 \pm 0,18$ & $31,74 \pm 0,73$ & $35,96 \pm 0,55$ & $35,82 \pm 2,06$ \\
Abu, \% BK & $16,95 \pm 0,59$ & $14,83 \pm 1,23$ & $12,07 \pm 0,08$ & $10,21 \pm 0,14$ \\
Protein kasar, \% BK & $53,78 \pm 0,63$ & $45,01 \pm 0,88$ & $37,87 \pm 0,73$ & $29,25 \pm 0,13$ \\
Lemak kasar, \% BK & $17,36 \pm 0,24$ & $15,42 \pm 0,44$ & $12,39 \pm 0,57$ & $9,95 \pm 0,45$ \\
\hline
\end{tabular}

Keterangan: $\mathrm{BK}=$ bahan kering 
Perbedaan aras gula kelapa pasta pada silase ikan rucah setelah 16 hari fermentasi meningkatkan kandungan bahan kering dan menurun abu, protein kasar, lemak kasar sedangkan serat kasar tidak terdeteksi. Hal ini disebabkan karena gula kelapa pasta $(75 \%$ BK) hanya mengandung karbohidrat, sehingga meningkatnya gula kelapa pasta menurunkan jumlah ikan rucah dalam pembuatan silase. Kandungan protein tertinggi $(45,01 \% \mathrm{BK})$ dari produk silase ikan rucah pada penambahan gula kelapa pasta $15 \%$ dibanding $30 \%$ dan $45 \% / \mathrm{kg}$ ikan rucah.

\section{KESIMPULAN}

Gula kelapa pasta $15 \% / \mathrm{kg}$ ikan rucah segar, merupakan campuran terbaik dalam fermentasi alami, mampu memproduksi asam laktat sehingga $\mathrm{pH}$ turun sampai nilai pengawetan $(<4,5)$. Meningkatkan kandungan amonia, non-protein nitrogen, bilangan peroksida dan asam lemak bebas hingga fermentasi hari ke-16. Fermentasi alami ikan rucah dengan penambahan gula kelapa pasta dalam pembuatan silase mempunyai potensi sebagai bahan sumber protein $(45 \%$ BK) dalam pakan ternak.

\section{DAFTAR PUSTAKA}

Abowei, J.F.N. and C.C. Tawari. 2011. Some basic principles of fish processing in Nigeria. Asian Journal of Agricultural Siences. 3(6): 437-452.

Ahamed, J. and N.S. Mahendrakar. 1996. Autolysis and rancidity development in tropical freshwater fish viscera during fermentattion. Bioresource Technology. 58: 247-251.

AOAC. 2002. Official Methods of Analysis. Asociation of Official Agricultural Chemists. Agricultural Chemical; Contaminats; Drugs Vol. 1. Asociation of Official Agricultural Chemists, Inc. Virginia.
Apriyato, A., A. Aristyani, Nurhayati, Y. Lidya, S. Budiyanto and S.T. Soekarto. 2002. Rate of browing reaction during preparation of coconut and palm sugar. International Congress Series. 1245: 275-278

Axelsson, L. 2004. Classification and physiology. In: Lactic Acid Bacteria: Microbiology and Functional Aspects (Eds. S. Salminen and A.P. Wright). New York Marcel Dekker, Inc. pp. 172.

Barker, S.B. and W.H. Summerson. 1941. The colorimetric determination of lactic acid in biological material. Journal of Biological Chemistry. 138: 535-554.

Dalgaard, P., H.L. Madsen, N. Samieian and J. Emborg. 2006. Biogenic amine formation and microbial spoilage in chilled garfish (Belone belone) effect of modified atmosphere packaging and previous frozen storage. Journal of Applied Microbiology. 101: 80-95.

Dapkevicius, M.L.N.E.N., M.J. Robert Nout, F.M. Rombouts and J. H. Houben. 2007. Preservation of blue-jack mackerel (Trachurus picturatus bowdich) silage by chemical and fermentative acidification. Journal of Food Processing and Preservation. 31: 454-468.

Fagbenro, O. and K. Jauncey. 1993. Chemical and nutritional quality of raw, cooked and salted fish silages. Food Chemistry. 48: 331-335.

FAO. 2004. International plan of action for the management of fishing capacity (IPOA-Capacity): Review of progress in Southeast Asia. TC IUU-CAP. Rome.

FAO. 2005. Asian fisheries today: The production and use of low value/trash fish from marine fisheries in the AsiaPacific region. FAO Regional Office for Asia and the Pacific. Bangkok. 
Ghaly, A.E., D. Dave, S. Budge, and M.S. Brooks. 2010. Fish spoilage mechanisms and preservation techniques: Review. American Journal of Applied Science.7(7): 859-877.

Gram, L. 2009. Microbial spoilage of fish and seafood products. In: Compedium of the Microbiological Spoilage of Feeds and Beverages. (Eds. W.H. Sperber and M.P. Doyle). Springer, London. pp. 87-119.

IBM SPSS Statistics. 2013. Version 22, IBM Corporation. USA.

Ndaw, A.D., M. Faid, A. Bouseta and A. Zinedine. 2008. Effect of controlled lactic acid bacteria fermentation on the microbiological and chemical quality of moroccan sardines (Sardina pilchardus). International Journal of Agriculture and Biology. 10: 21-27.

Nielsen, S.S. 2010. Food Analysis. 4th ed., Springer. London.

Pearson, D. 1971. The Chemical Analysis of Food. 6th ed., J \& A Churchill, London.

Raia, A.K., H.C. Swapnaa, N. Bhaskara, P.M. Halamib and N.M. Sachindraa. 2010. Effect of fermentation ensilaging on recovery of oil from fresh water fish vicera. Enzyme and Microbial Technology. 46: 9-13.

Repetto, M., J. Semprine and A. Boveris. 2012. Lipid peroxidation: chemical mechanism, biological implications and analytical determination. In: Lipid
Peroxidation. (Ed. A. Catala). InTech. Croatia. pp. 3-30.

Rustad, T., I. Storro and R. Slizyte. 2011. Possibilaities for the utilisation of marine by-products invited review. International Journal of Food Science and Technology. 46: 2001-2014.

Sachindra, N.M. and N. Bhaskar. 2008. Invitro antioxidant activity of liquor from fermented shrimp biowaste. Bioresorce Technology. 99: 90139016.

Schneider, O., V. Sereti, E.H. Eding and J.A.J. Verreth. 2006. Molasses as C source for heterotrophic bacteria production on solid fish waste. Aquaculture. 261: 1239-1248.

Teclu, D., G. Tivchec, M. Laing and M. Wallis. 2009. Determination of the elemental composition of molasses and its suitabilaity as carbon source for growth of sulphate-reducing bacteria. Journal of Hazardous Materials. 161: 1157-1165.

Wheatherburn, M.W. 1967. Fenolhypoclorite reaction for determination of ammonia. Analytical Chemistry. 39: 971-974.

Zahar, M., N. Benkerroum, A. Guerouali, Y. Laraki and K. El Yakoubi. 2002. Effect of temperature, anaerobiosis, stirring and salt addition on natural fermentation silase of sardine and sardine wastes in sugarcane molasses. Bioresource Technology. 82: 171-176. 